Between Sect and State in Lebanon: Religious Leaders at the Interface

Author(s): Alexander D. M. Henley

Source: Journal of Islamic and Muslim Studies, Vol. 1, No. 1 (May 2016), pp. 1-11

Published by: Indiana University Press

Stable URL: http://www.jstor.org/stable/10.2979/jims.1.1.02

Accessed: 24-10-2016 21:24 UTC

JSTOR is a not-for-profit service that helps scholars, researchers, and students discover, use, and build upon a wide range of content in a trusted digital archive. We use information technology and tools to increase productivity and facilitate new forms of scholarship. For more information about JSTOR, please contact support@jstor.org.

Your use of the JSTOR archive indicates your acceptance of the Terms \& Conditions of Use, available at http://about.jstor.org/terms

Indiana University Press is collaborating with JSTOR to digitize, preserve and extend access to Journal of Islamic and Muslim Studies 


\title{
Between Sect and State in Lebanon: Religious Leaders at the Interface
}

\author{
Alexander D. M. Henley
}

\begin{abstract}
Muslim communities in Lebanon have developed radically new institutions of religious leadership since the advent of the confessional state. These leaderships were created or refined over the course of Lebanon's first five decades (1920s-1970s), often building on pre-existing institutional norms but shaped by common patterns of integration into a state-centric system of confessional representation. Such institutions have played a key role in representing and reinforcing the sectarianisation of Islam in the country. On the other hand, their proximity to the state has made them prominent advocates of peaceful coexistence and political participation. This paper shows (1) how three Islamic religious leaderships have become institutional expressions of a distinctive Lebanese sectarianism, and (2) how they have in the process become defenders of the nation-state. Focusing on the Sunni office of mufti, this leadership is surveyed alongside its Shi'i and Druze counterparts to highlight their convergence on a single institutional model. These developments began in response to a French colonial demand for interlocutors with religious communities, and gained urgency as these interlocutors negotiated communal autonomy in religious affairs. The project of communal self-governance which included jurisdiction over personal status law - called for centralized religious institutions that could manage nationwide bureaucracies. Thus a Sunni mufti, Shi $i$ sheikh, and Druze sheikh al-aql were each elevated to leadership of new religious hierarchies. While competition among these three leaderships played a part in their development, this paper uses the history of the 1975-90 civil war to show how their common enculturation into the life of the state has generated a strong centripetal tendency in their political behavior.
\end{abstract}

\footnotetext{
Alexander D. M. Henley is the American Druze Foundation Postdoctoral Fellow at the Center for Contemporary Arab Studies, Georgetown University, Washington, DC. His special fields of interest include religion and politics in the modern Middle East, with a special interest in the phenomenon of sectarianism in the Middle East. He completed his Ph.D. at the University of Manchester, England, with a dissertation that explored the construction of a religious elite in modern Lebanon and compared the roles of Sunni $m u f t i$ and Maronite patriarch in contesting sectarian identity production during the $1975-90$ civil war. He is writing a book provisionally entitled Religion and State in Lebanon: Religious Leadership, Sectarianism, and Civil War.
} 


\section{Introduction: \\ State and Society in the Study of Sectarianism}

Sectarianism has never been spoken about nor written about more than today. ${ }^{1}$ It has come to be treated as a defining feature of Islamic and especially Middle Eastern societies, part of the Orientalizing imagination of an Islamic world that is unfathomable to the secular citizens of Western states. Various key events over recent years and decades have prompted successive and escalating discussions of sectarianism. Iran's (Shi i) Islamic Revolution in 1979 and subsequent Iran-Iraq war in the 1980s raised the question of sectarianism as a driver of regional conflict. That idea has been reinforced by the sectarian thread apparently running through Iraq's civil war in the mid-2000s, the current conflicts in Syria and Yemen, and harsh repression of Shi' is in Bahrain and Saudi Arabia. What these troubles of the past decade have in common is that sectarianism usually gained force in the wake of challenges to longstanding authoritarian regimes: first the removal of Saddam Hussein's government in Iraq, then the region-wide revolutionary tide of the Arab Spring. This observation has led to a popular imagination of sectarian tension as something inherent in Muslim or Arab society, a proclivity that may be contained by a muscularly "fierce" state, ${ }^{2}$ but that threatens to boil over into violence when the state falters or fails. Hence every time these countries try to take one step forward towards modern democracy, sectarianism drags them two steps backward. Since the opposition between sectarianism and the modern state has been such a major focus of this discussion - both in the public sphere and in academia - this article will investigate that relationship further, using examples from Lebanon.

Lebanon has of course been the Arab world's quintessential example of sectarianism ever since it was created in 1920. It was framed by colonial statebuilders and then by the architects of independence in 1943 as a state of compromise between confessional groups. That compromise came to be known as the "National Pact," the Lebanese state's answer to the sectarian beast thought to be lurking in its recent past. When conflict recurred, it was ascribed to the re-awakening of a sectarianism that threatened to drag the Lebanese back into chaos, the answer to which was to reinforce loyalty to the nation and investment in the National Pact's state. But if the modern state is seen to be the vorpal sword that may finally slay the region's ancient beast, it also presents a paradox, as recognized by veteran journalist Robert Fisk. "For, to be a modern state, Lebanon must de-confessionalise itself. A nation in which the president must always be a Maronite Christian, the prime minister a Sunni, the speaker of parliament a Shi'a, cannot work. But if you take sectarianism out of Lebanon, it will cease to exist - because confessionalism is the identity of Lebanon." ${ }^{3}$ What Fisk captures here is the simultaneity and even symbiosis of sectarianism and nationalism, 
along with the resulting ambiguity of modernization as progress. Strong modern states are hailed as the answer, but can we really disentangle them from the problem they are supposed to solve? Just because sectarianism seems so often to rear its head when states weaken or fail, can we assume that it is the absence of the state - not its historical formation - that is responsible for sectarianisation? Much as Lina Khatib warned us not to assume, in the messy wake of the Arab Spring, that the Middle East is "better off with its dictators" who she says in fact "plant the seed of future unrest," "so I suggest we should be careful not to dissociate wartime sectarianism from the pre-war national order.

Fisk, in summing up the paradox of modern sectarianism in Lebanon, points to that state's particular combination of national institutions with sectarian leadership: constitutional offices are allotted according to confessional group. This system is presented as a perversion of the unifying function of national institutions in a modern state. In this article, I will explore the workings of those institutions conventionally understood to represent the antithesis of national unity in Islamic and Middle Eastern societies. As Rola El-Husseini neatly puts it, "Commitment to the nation comes after loyalty to the family, the personal representative of one's interests [the $z a^{\prime} i m / z u^{\prime} a m a^{\prime}$, in Lebanese parlance], and the clerical leader of one's sect."' Putting aside the roles of kinship networks and $z u^{\prime} a m a$ ' for now, this article will focus on the third type of institution associated with divisive identities, namely the clerical leaders of sects. As in other Islamic and Middle Eastern countries, the religious heads of Islamic and Christian sects play a significant and controversial role in Lebanese politics: their opinions receive a national platform, and they are routinely consulted by politicians, diplomats, and foreign heads of state. The persistence of such powerful religious leadership in Lebanon has posed a longstanding conundrum in the scholarship on modernization, secularization, and sectarianism. Various explanations have been given. One is that national identity has never fully taken root, and primordial loyalties to religious leaders have therefore remained primary. ${ }^{6}$ Another is that such traditional clerical leaderships (and the communal order they represent) provide a kind of institutional security in the face of state weakness, and thus are periodically able to reassert their temporal authority when constitutional institutions fail. ${ }^{7}$ Other explanations point to specifically regional Islamic dynamics such as the rise of Islamism or a Shi'a Awakening. I suggest, however, that the question that has been posed is the wrong question. These institutions have not persisted despite the state-building process, but on the contrary exist in their current forms precisely because of it. In this light, the notion of a zero-sum game between sect and state or sectarianism and nationalism falls apart. I will first survey the origins and development of the religious institutions that stand today for confessional groups in Lebanon, and then look at their roles in the production of identity. 


\section{Religious Leaders and the Representation of Society as Religiously Divided}

On the face of it, it looks as though religious leaders are an age-old part of Lebanese public life. Each community has a head who claims to represent a lineage or tradition of leadership going back centuries, with its own distinctive titles and styles of dress. The Sunnis have a mufti on the Ottoman model, the Shi'a have sheikhs or imams, the Druze have the sheikh al-aql, and the various Christian groups have patriarchs or bishops. If we look more closely, however, we see a great deal of change across the board in the twentieth century. But the picture is a confusing one. The Sunnis transformed their "Mufti of Beirut" into a "Mufti of the Lebanese Republic" in the 1930s. The Shi' $i$ "Imam" Musa al-Sadr established himself in the 1960s as President of the newly created Higher Shi'i Islamic Council. The Druzes had two leaders bearing the title "Sheikh al-Aql" until one line was suppressed in 1970. At different times and in different ways, all three Islamic leaderships underwent considerable institutional growth and consolidation in the first half century of Lebanese statehood, each building a stately headquarters to reflect its dignity as representative and head of its community. On the Christian side, by contrast, many accounts have been written of the decline of the Maronite patriarchs, a lineage going back more than a millennium. ${ }^{8}$ Scholars of each community have tended to explain these ups and downs in different ways according to their particular religious and social histories. Yet a common pattern emerges when we view them side by side.

If it were possible to map out these various changes on a chart spanning the twentieth century, I suggest that what we would see is a convergence of trajectories. Coming from very different starting points, they rose or fell in political influence more or less rapidly to a roughly equivalent status in Lebanese public life. They certainly preserved the flavors of their distinctive histories and religious traditions, but in crucial ways developed towards a common institutional model of Lebanese religious leadership. So despite their different hats, turbans, robes, and titles, what we see is a single model consisting of a unitary figurehead headquartered in Beirut who stands both as the officially-recognized representative of a Lebanese community and the head of a nationwide clerical hierarchy. The leader is elected from the clerical corps and holds executive authority in conjunction with a legislative council of which he is president. The state grants each leader certain quasi-diplomatic privileges including a security detail, a degree of immunity, and the highest rank in formal protocol besides the president of the Republic. The state also recognizes each confessional council's right to legislate on the personal status and other affairs of its community, and to manage its own portion of the state budget. These laws are published in the parliamentary gazette, upheld by the courts, and enforced by the police. 
Going into a little more detail about the case of the Sunni mufti will give a sense of how fundamental these transformations were, and how they came about. The story begins prominently on 1 September 1920, when the State of Greater Lebanon was created under French Mandate. On the day of its proclamation, the French High Commissioner invited numerous dignitaries to attend, but he gave places of honor to two men in particular. On his right sat the Maronite patriarch as representative of Lebanon's Christians, and on his left sat a Sunni mufti as his opposite number, representative of the Muslims. The High Commissioner's intention, of course, was to show the new state as a historic marriage of constituent religious communities, embodied in their two leaders. What is interesting about this grand symbolic occasion is that it represented an imagined vision of confessionalism as common sense, and in so doing paved the way for the imaginary to become real.

The Mufti of Beirut, Sheikh Mustafa Naja, had to be coerced into attending the proclamation ceremony in 1920, not only because he did not approve of the new state, but also, I would suggest, because he did not consider himself a leader. The day before, Naja had been sitting at a stall in the souq, where his job as mufti was to distribute fatwas to those who came with questions of sharia. Since this function did not require all of his time, Naja also taught at the grand mosque and helped his father run the family's perfume shop nearby. The French High Commissioner symbolically recast this mufti from a comparatively minor provincial legal official into the religious leader of a community, and a little over ten years later his successor was styled as "Mufti of the Lebanese Republic." The colonial state's recognition of the rights of religious communities proceeded to drive a comprehensive restructuring of clerical institutions that put the mufti in charge of a professionalized and hierarchical Sunni religious corps. I do not think it a coincidence that the new Islamic religious hierarchy resembled that of a Christian Church. On the Christian side of the equation, the Maronite Church ended up creating a legal code and court system that mimicked Islamic practice. Thus the practice of sectarian organization in each community came to mirror the others, all within the framework of a colonial discourse of religion that shaped expectations of what a religious leader should look like.

Sheikh Naja may have been reluctant to embrace the language of religion and religious leadership coming into force in the Mandate's brave new Lebanon, but he nevertheless began to use his perceived status as "le mufti des musulmans" to petition mandatory officials. Although known for making stands against core French policies such as the separation of Lebanon from Syria, Naja also engaged the colonial government in negotiations over practical questions of administration, especially where they concerned shari'a courts and Islamic endowments. Difficult as French officials may have found the mufti, they appear to have continued treating him as legitimate representative of his community. Having the 
government's ear, he started to become a useful interlocutor for both sides, so members of the community increasingly asked him to intercede on their behalf. It is reported that Naja even received such a delegation - a group of disgruntled drivers - on his deathbed, penning his last letter of complaint mere hours before succumbing to sickness. ${ }^{9}$

The new model of religious leadership was established in practice through the interaction between colonial officials and their local subjects. This began with a politics of demand articulated by men like Sheikh Naja, men who would not necessarily give up their resistance to colonial rule and colonial borders, but who were prepared in the meantime to make claims on the government in power. In a framework of confessional representation, those demands seemed more effective when presented by a religious leader, and when made in the name of religious or communal rights. Over the following decades, as the interplay between recognition and demand made Lebanese citizens increasingly conscious of their sectarian affiliation, so the religious leaders were raised up as symbols of the dignity and national standing of their communities. It was not necessary for government to drive the institutionalization of religious leadership; the growing culture of sectarian competition made it a matter of pride and expediency that one's religious leader should have all the rights, powers, and privileges possessed by the others, if not more.

\section{Religious Leaders as Representatives of the State to the Sect}

It is important to realize that the colonial state did not simply preserve a pre-modern sectarian social order, but created an altogether new system of communal administration embedded in the principles and institutions of the power-sharing political regime. Yet all this change was framed by its colonial architects as a simple matter of legal recognition of a religious mosaic they imagined was already there. Common sense told European colonizers that religion defined Oriental society, and that religions would have religious leaders with whom they could deal as natural interlocutors, each representing their sectarian current. Lebanon's religious leaderships were paradoxically created with a primordial character, which continues to define the discourse around them to the present day. Even their fiercest critics, who decry the interference of religious leaders in secular politics, frequently imply that these leaders do indeed naturally represent the sectarian extremes of Lebanese society. So who do the religious leaders represent? And how responsible are they for the problem of sectarianism in Lebanon today?

On one hand, these figures play a well-documented role in the maintenance of vertical divisions in society. They administer separate personal status regimes that place every citizen more or less rigidly within a subset of the population, 
inhibiting intermarriage across communal lines. ${ }^{10}$ They also administer confessional schools, universities, hospitals, and other services that socialize individuals from an early age into communally-bounded lives. ${ }^{11}$ Their very existence as prominent public representatives of sects could also be said to reinforce perceptions of difference or notions of communal loyalty as primary - whether or not it was intended. Yet on the other hand, their relation to communal populations is hardly organic. Their status as leaders is not primarily dependent on followership or any kind of charismatic relationship, ${ }^{12}$ nor does the common assumption that a religious leader naturally represents his community's religious essence stand up to any scrutiny.

The leaderships we are talking about here are constituted first and foremost by their relation to state infrastructure; they are embedded in the culture of a state-oriented elite. This elite station is consistently reflected in their political decision-making. At key moments in Lebanese history, these official religious leaders have chosen to oppose the dominant political currents or mainstream public opinion within their own communities. One such time was the civil war of 1975-90. During a period when political discourse was frequently dominated by sectarian logics of communal self-defense, each of the official religious leaders came out in opposition to armed action of any kind. While all of them supported regime reform - which was a key issue of contention in the war - they refused to envision any route to reform other than through constitutional institutions. Better to surrender some of our rights and privileges as a community, they said, than to undermine the sovereignty of the state that belongs to all of us. They backed up this statist policy with a common vision of Lebanon as final national homeland for all. In a nation of brother citizens there is no sectarian "other" to distrust or defend against. Most powerfully, I think, they turned the tables on the sectarian discourse of righteous believers versus treacherous unbelievers, which was peddled increasingly by certain militias. Subverting that discourse, the official religious leaders pushed a social vision in which believers were the good pious citizens of all sects who kept faith in the nation-state and suffered at the hands of unbelieving, uncivil militiamen. If such rhetorical strategies perhaps sound naïvely ineffective in the face of militarized politics, the militias of the time did not agree. The religious leaders of Lebanon's sects effectively made themselves outcasts within their own communities, systematically persecuted and increasingly isolated voices as other dissenters were driven into exile or assassinated. The same fate eventually caught up with the mufti, Hassan Khaled, who was killed by a car bomb in 1989, the explosive finale of a long-running campaign of threats and violence against the representatives and incumbents of the top religious offices.

In the aftermath of the 1975-90 war, these religious leaderships emerged as strong as or stronger than ever, receiving even greater official recognition in the 
post-war constitution. Some say that the renewed prominence of religious leaders today reflects the heightened sectarian polarization of Lebanese society in an era still largely defined by wartime divisions, animosities, and even personalities. That view, shaped by assumptions of a natural connection between religious leaderships and sectarian masses, glosses over the far more complex history of clerical politics in the twentieth century. On the contrary, the official religious leaders emerged from the war in force because they came out on the winning side: it was their model of a strong central state with a moderately adjusted power-sharing system that was enshrined in the Ta' if Agreement of 1989. Whereas the various Lebanese protagonists of the civil war adopted the face-saving slogan "no victor, no vanquished," and were by and large able to reintegrate themselves into peacetime politics, the religious elite were among the few real victors. Militia leaders had achieved neither their opposing political projects - whether the Christians' preservation of their power-sharing guarantees or the Leftists' complete abolition of the confessional power-sharing system - nor their parallel paramilitary projects to maintain and entrench their hegemony over confessionally-circumscribed populations and territories. Restoration of a (modified) National Pact regime with unified territorial sovereignty was precisely what the mufti and other official religious leaders had called for, along with some other members of the pre-war elite who had stayed out of the militia business.

Lebanon's official religious leaders have continued to use their public prominence to advocate for constitutional politics and the National Pact formula of coexistence. Wartime experience of their potential to challenge the mainstream parties' extensive control over public discourse (not least through their overwhelming dominance of Lebanese media) has led the parties to target these institutions' independence wherever possible. The result has been a series of crises within the religious leaderships as they became battlegrounds of political contestation, especially around vulnerable moments of succession. The Sunni, Shi $i$, and Druze leaderships all experienced prolonged succession crises in the 1990s and 2000s, as parties intervened to stall or manipulate their internal electoral processes, often with the assistance of the Syrian regime's hegemonic presence in Lebanon. Nevertheless, religious leaders once in office have been able to take notable stands against antagonistic politics and the practice of brinkmanship that repeatedly threatens to paralyze constitutional institutions for partisan gain.

In 2012, Mufti Muhammad Rashid al-Qabbani clashed with Saad Hariri's Future Movement, the largest force in the Sunni community, over his meetings with Hezbollah representatives and the Iranian ambassador aimed at defusing Sunni-Shi'i tensions. This upset the Future Movement's anti-Hezbollah agenda so much that Hariri spent the next two years working to engineer Qabbani's ouster from office, which he finally achieved in 2014. Meanwhile, Higher Shi'i 
Council President 'Abd al-Amir Qabalan was calling for Hezbollah to surrender its weapons to the state and stop sending fighters to Syria, which he saw as destabilizing communal relations in Lebanon. On the Christian side, Maronite Patriarch Beshara al-Ra'i caused an outcry among major parties within his community in the first year after his 2011 election by staging his own rapprochement with Hezbollah in an attempt to bridge the intensifying political divide. Each such move to promote national unity has been met with scathing criticism for threatening the communal interest as defined by sectarian parties. What the various religious leaders have consistently demonstrated, however, is their common vision of the communal interest as inextricably tied to the proper functioning of state institutions, which are to be approached not as a resource for factional exploitation but as an essential framework for national unity and sovereignty.

\section{Conclusion}

These Lebanese religious leaders make a useful case study in a discussion of sectarianism because their story is full of ironies and seeming contradictions that should keep us on our toes when treating this delicate and complex subject. Conventional wisdom tells us that the religious heads of sects should be walking embodiments of sectarianism. They are after all the prime enforcers of social segregation, and their job description - as written in Lebanese law - is to represent their sect to the state. Yet in practice we find these religious leaders acting as representatives of the state to their sect. That is, representing the ideology of the Lebanese state and its national values - expressed in the National Pact formula of coexistence - and championing the state's institutional interests above the widely perceived factional interests of their individual sects. In the account I have very briefly sketched, we see sectarian and national institutions as contemporaneous, their powers symbiotic, and their ideologies harmoniously blended.

This case study raises several interconnected questions about sectarianism. Can we talk about any particular kinds of institutions, or forms of organization, as definitively sectarian as opposed to national? Does religious nationalism have to be a problem in multi-confessional countries? And in instances of sectarian civil war, is state failure a sufficient explanation of the resort to communal fault-lines and mobilization? While the particular details of the Lebanese case, and of its religious institutions in particular, cannot necessarily be generalized to all Islamic or Middle Eastern societies, it can certainly put us on guard against certain easy misconceptions. Clearly we cannot assume that the existence of communally-based institutions is antithetical to broader social cohesion within modern states. Indeed in focusing on sectarianism as a Middle Eastern problem we are perhaps prone to forgetting that the sociological binary of traditional communal social organization (Gemeinschaft) versus 
modern association social organization (Gesellschaft) is not as clear-cut even in Western nation-states as Max Weber and others might once have thought. Is the state really the only, or even the primary, mediator of national belonging in modern liberal democracies? Lynn Staeheli's studies of local community associations in the global north, for instance, suggest that "Rather than the autonomous citizen who participates in a clearly defined, analytically distinct public sphere governed by a sovereign entity that is assumed in liberal theories of citizenship, these examples [including families, informal markets, and residents' associations] highlight the complex interrelationships that structure a field in which a subject - a citizen - might operate." ${ }^{13}$ The notion that national belonging may arise out of complex social interrelationships beyond the state opens the door to a recognition of sub-state actors in the Middle East, including religious leaders of different sects, as potential producers of cohesive national identities and values, and of confessional communities as potential sites of citizenship formation.

The flip side of questioning a generic category of sectarian actors, institutions, or modes of organization, of course, is to complicate our idealized view of the state as the representative and driver of cohesive nationalism. Just as national identity is not only handed down to citizens by states, but may also be mediated through numerous other kinds of institutions and public spaces, so the state may be equally culpable in the production of divisive identities as substate sectarian actors. Whereas the history of sectarianism in Lebanon is often read backwards from the post-war period as being defined by the virtual absence of the state, we find the state in fact heavily implicated in the articulation and institutionalization of communal identities from its colonial beginnings through the period of independence. ${ }^{14}$ It would surely be facile to see the radicalization of confessional loyalties in wartime Lebanon - or Iraq, or Syria, for that matter as simply emerging from the chaotic state of nature that remains when the civilizing influence of the state is stripped away from Arab or Muslim society. This projection of Thomas Hobbes' vision of a violent primordial society onto the present, with the Orientalizing twist of sects as its natural social units, reduces any analysis of sectarian conflict to a mere absence of modern order, artificially removing it therefore from its very modern historical context. What is obscured is the extent to which group socialization of all kinds - national and sectarian - may be shaped by the influence of the state's totalizing administrative (re-)categorization of society into manageable units. If we are to understand the current rise of sectarian conflict in Islamic and Middle Eastern societies, and especially if we are successfully to bend state institutions to the task of solving this problem, we must first understand how these states have themselves been implicated in "planting the seeds" of sectarianism. ${ }^{15}$ 


\section{Endnotes}

1. This upward trend has been especially evident over the past ten years. The New York Times, for instance, ran just four articles including the word "sectarianism" (of which only two related to the Middle East) and 78 including the word "sectarian" in 2003 (of which fewer than half related to the Middle East), whereas by 2006 such articles numbered 43 and 1081 respectively (with an overwhelming focus on the Middle East). These trends and full archives can be viewed using the publication's own analytical tool at http://chronicle.nytlabs.com, accessed March 20, 2016.

2. A term usefully coined by Nazih Ayubi, Over-stating the Arab State: Politics and Society in the Middle East (London: I.B. Tauris, 1995).

3. Robert Fisk, "Lebanon is like a Rolls Royce with square wheels ... it has a lot that's worthy of praise but it doesn't run so well," The Independent, March 24, 2013, http://www.independent .co.uk/voices/comment/robert-fisk-lebanon-is-like-a-rolls-royce-with-square-wheels-it-has-a -lot-that-s-worthy-of-praise-8547463.html.

4. Lina Khatib, "Was the Middle East better off with its dictators?," CNN Opinion and Carnegie Middle East Center, March 27, 2015, http://carnegie-mec.org/2015/03/27 /was-middle-east-better-off-with-its-dictators.

5. Rola El-Husseini, "Lebanon: Building Political Dynasties," in Arab Elites: Negotiating the Politics of Change, ed. Perthes Volker (London: Lynne Rienner, 2004), 239-266, 254.

6. E.g. Rola El-Husseini in ibid.

7. The conclusion drawn for example in Fiona McCallum's work on Christian Religious Leadership in the Middle East: The Political Role of the Patriarch (London: Edwin Mellen Press, 2010).

8. E.g. ibid; Fiona McCallum, “The Role of the Maronite Patriarch in Lebanese History: The Patriarch of Lebanon?," Chronos (2007): 65-88; Jurj Harun, Tarikh al-Batarika al-Mawarina (Beirut: 2009); Seely Beggiani, “The Patriarchs in Maronite History”, Journal of Maronite Studies 5 (2001); David Kerr, “The temporal authority of the Maronite Patriarchate, 1920-1958: a study in the relationship of religious and secular power," DPhil Thesis, University of Oxford, 1973.

9. Taha al-Wali, Bayrut fi-l-tarikh wa-l-hadara wa-l-umran (Beirut: Dar al-Ilm li-l-Malayin, 1993), 305.

10. There is a considerable literature on Lebanese personal status regimes, including Sofia Saadeh, The Quest for Citizenship in Post-Taef Lebanon (Beirut: Sade, 2007); and Mark Farha, "Stumbling Blocks to the Secularization of Personal Status Laws in the Lebanese Republic (1926-2013)," Arab Law Quarterly 29/1 (2015): 31-55.

11. On the socialization of sectarianism through service provision in Lebanon (albeit with a focus on political parties rather than religious institutions), see Melani Cammett, Compassionate Communalism: Welfare and Sectarianism in Lebanon (Ithaca: Cornell University Press, 2014).

12. Conceptions of sectarian leadership discussed in various chapters of Franck Mermier and Sabrina Mervin, eds., Leaders et partisans au Liban (Paris: Karthala, 2012).

13. Lynn A. Staeheli, "Political geography: Where’s Citizenship?" Progress in Human Geography 35/3 (2010): 393-400, 398. See also Staeheli, "Citizenship and the Problem of Community," Political Geography 27 (2008): 5-21.

14. This dovetails with Ziad Abu-Rish's yet unpublished work on the Lebanese state's role in shaping the "laissez-faire" economy, which is also generally conceived in terms of state absence. See his interview with the Lebanese Center for Policy Studies, May 12, 2015, http://www .lcps-lebanon.org/agendaArticle.php?id=49.

15. Lina Khatib's words, cited above. 